Article

\title{
Can Local Institutions Help Sustain Livelihoods in an Era of Fish Declines and Persistent Environmental Change? A Cambodian Case Study
}

\section{Melissa Marschke ${ }^{1, *}$, Ouk Lykhim ${ }^{2}$ and Nong Kim ${ }^{3}$}

1 School of International Development and Global Studies, Faculty of Social Sciences, University of Ottawa, 120 University Private, Ottawa, ON K1N 6N5, Canada

2 Conservation International, B1-4 Phnom Penh Center, Phnom Penh, Cambodia; E-Mail: louk@conservation.org

3 General Department of Administration for Nature Conservation and Protection, Ministry of Environment, 48 Preah Sihanouk Boulevard, Phnom Penh, Cambodia E-Mail: moepmcr@gmail.com

* Author to whom correspondence should be addressed; E-Mail: mmarschk@uottawa.ca; Tel.: +1-613-562-5800 (ext. 4866); Fax: +1-613-562-5817.

Received: 11 February 2014; in revised form: 15 April 2014 / Accepted: 16 April 2014 / Published: 30 April 2014

\begin{abstract}
This paper sets out to explore fishers' perceptions of environmental change in coastal Cambodia and to then examine the role of local institutions in working with villagers to adapt to such challenges. The analysis shows that: (1) fishers observe species decline, irregular tides and a change in weather patterns; and (2) local institutions have been working to address some of these issues through a series of resource management and livelihood projects for over a decade. We note that local institutions are well placed to deal with certain types of environmental change projects, such as protecting small patches of mangrove trees or creating fish sanctuaries, along with less controversial, tourism-related projects. It is impossible, however, for local institutions to tackle bigger issues, such as over-fishing or large-scale resource extraction. Fishing villages are dealing with multiple challenges (environmental change and beyond), which may make fishing a less viable option for coastal villagers in the medium to long term. As such, key policy responses include acknowledging and building upon the work of local institutions, enhanced support for patrolling at national and provincial levels, developing response scenarios for coastal environmental change, involving local institutions in scientific monitoring and piloting projects that consider fishing and non-fishing livelihoods.
\end{abstract}


Keywords: small-scale fisheries; environmental change; perceptions; institutions; livelihoods; Cambodia

\section{Introduction}

Fishers, particularly those living in resource-dependent villages, rely upon natural resources for much of their livelihood. The vitality of these natural resources are influenced by multiple environmental change factors, including climate variability [1] and fishery management [2]. Evidence of coastal environmental change include fluctuations in water temperature, precipitation and oceanographic variables (wave action, sea level rise), all of which can bring about significant ecological and bio-physical changes directly impacting people whose livelihoods depend on those ecosystems [3]. Compounding this is the prediction that rising sea temperatures will result in certain fish species extinctions in the tropics and sub-polar regions, coupled with species invasions of fish migrating into cooler waters [4]. This suggests major ecological disturbances, particularly as we move beyond $2{ }^{\circ} \mathrm{C}$ of warming, whereby social ecological systems may transform into new, unanticipated states [5]. Meanwhile, fishery decline and species loss is already proving to be a major issue, with the majority of the world's fish stocks being maximized [6] and regional fishery policies not being enforced [7]. For many small-scale fishers, pressure on fish stocks and coastal resources has increased, while overall incomes and employment has declined, further marginalizing often impoverished households [8]. Environmental change is a major issue for the fishery sector and for fishing households, particularly in the global South, where the majority of fishers live [9].

Extreme events have highlighted significant deficiencies in prevention and preparedness in dealing with environmental change, particularly in the global South [10]. One response by the donor community has been to increase funding for climate change adaptation projects. Such projects include focusing on low carbon development, conducting vulnerability assessments and specific projects to help communities deal with climate change [11]. This current emphasis enables donors to continue to fund village-level initiatives, including infrastructure-related projects, particularly in the environment sector, where market-oriented conservation (certification, payment for ecosystem services) programs have gained in popularity $[12,13]$. Adaptation approaches used by development practitioners may draw from the work done on sustainable livelihoods [14], capabilities and entitlements [15,16] and land degradation, hazards and risk [17,18]. This work highlights how adaptation in villages is linked to both adaptive capacity and local vulnerabilities [19]. In spite of a wave of criticism suggesting that current adaptation efforts are unfocused, this is an area of development intervention that will continue to grow given the vulnerabilities facing many populations [11].

Our focus is on coastal Cambodia, an area that has seen significant environmentally-focused development interventions since the late 1990s [20]. Local institutions (which include formal institutions such as a commune council, a community fisheries committee, or a community-based protected areas committee or informal institutions such as a group of elders, or Pagoda leaders) observe environmental change first hand and have undertaken adaptation-related projects within community-based natural resource management (CBNRM) programs in the mangrove-estuary villages 
of coastal Cambodia. More recently, funding for adaptation work has been ramping up: for example, the World Bank has committed 86 million dollars for a pilot program in climate resilience focusing on the water, agriculture, food security and infrastructure sectors [21]. Some of these funds will be allocated to local institutions, likely in coastal areas given general coastal vulnerabilities. Yet, little analysis, other than a few working papers [22-25], has taken place regarding fishery decline, environmental change and the role of local institutions in Cambodia. There has been no assessment of: (1) past projects and practices; (2) what is doable at a local level compared to what needs to be addressed at other scales; or (3) priority areas of focus for funding. Our paper seeks to address this research gap.

We begin our paper with a brief overview of common property theory, before outlining Cambodia's policy framework for decentralization and support for local forms of resource management. We then turn to our case study, examining local perceptions of environmental change and considering if on-going community-led projects can address such issues. Villagers and local institutions [26] hold strong perceptions of environmental change and are an important resource in the absence of baseline monitoring. Local institutions are well placed to deal with certain kinds of adaptation measures, such as small-scale, less controversial protection or tourism-related projects. It is impossible, however, for local institutions to tackle bigger issues, such as over-fishing or large-scale resource extraction. We conclude by suggesting that fishing villages are dealing with multiple challenges (environmental change and beyond), which may make fishing a less viable option for coastal villagers in the medium to long term. As such, priority focus areas include developing response scenarios for coastal environmental change, involving local institutions in scientific monitoring, piloting projects that consider fishing and non-fishing livelihoods for coastal villagers and enhanced support for patrolling at national and provincial levels.

\section{Cambodia's Policy Framework for Encouraging Village-Level Involvement}

Decentralization marks progress in public accountability, environmental sustainability and empowerment of poor and vulnerable groups [9], since it is a mechanism designed to bring citizens, local groups and organizations into the policy and decision-making process [27]. Within the environment sector, the push for decentralized resource governance was in part a reaction to "command and control" resource management [27] and also drew on insights from commons scholarship, following from the extensive research done by Elinor Ostrom [28] and others [29-32]. Commons research has shown how community groups are capable of managing resources given certain conditions and appropriate incentives. Increasingly, it is recognized that government involvement is an essential component of commons management [33]. The characteristics of a resource, levels of trust among actors and rules in use also play an important role [34]. Most examples of common pool governance are small scale, single case and cover short time periods (a few months).

Common property management does have its challenges. For example, it can be part of a general off-loading of responsibility to lower management units [26]. This type of management arrangement becomes particularly challenging where resources are transboundary and in areas with high poverty rates [31]. Even with a plethora of new policy supporting commons management and collective rights arrangements, getting the right fit between collective goods (conservation) and individual benefits 
(livelihoods) remains problematic [20]. Much of the common property and collective-action literature has focused on the characteristics of the user group and the attributes of the resources [35]. Thus, there is a need to consider the role of external influences [36] and to take a longer-term perspective to understand the sustainability of community-led actions over a number of years [37].

This emphasis on local governance and collective rights is in line with the development thinking of donors and multilateral lending agencies [32] and plays out in the environmental sector within Cambodia, in so far as the Ministry of Environment, the Fisheries Administration and the Forestry Administration have each created legislation enabling local involvement in resource management (i.e., the creation of community forestry, fisheries and resource management committees). Over 300 village committees are working on forestry issues, 469 on fishery issues and over 50 on issues within protected areas [24,38]. Since the early 2000s, the Cambodian government has passed significant legislation supporting decentralization measures [20]. Cambodia is the only country in Asia with such a significant policy thrust on 'small scale-isation' within the environment sector [25]. A series of sub-decrees are in place to support local forms of resource management [20], complemented by national-level plans that further encourage institutions being involved in general forestry/fisheries, or protected area conservation or protection measures [38-40].

While significant plans exist to support actions at a village or commune level, plans tend to be sectoral rather than cross-cutting and do not necessarily build on past experiences [20]. For example, within the 2006 National Priority Action Plan (NAPA), several projects focussed on coastal issues, including rehabilitating coastal infrastructure and the sustainable use of natural resources. The challenge is that these projects have not yet been piloted are written in general terms and are not linked specifically with the fishery sector [39-41]. The latest NAPA notes that sea level rise is a coastal risk: no specific suggestions are made regarding how to deal with sea level rise. Cambodia's Strategic Planning Framework for Fisheries, 2010-2019, mentions climate change as a threat to fisheries; little detailed information is given as to what this means. While planning documents touch on key issues, there remains little assessment, analysis and reflection on how to concretely deal with environmental challenges, particularly with respect to coastal villages and the fishery sector (there has been greater emphasis in the forest sector related to carbon credits [42]). Meanwhile, fishery committees and coastal protected area committees do exist, and some have been working on fisheries, resource governance or environmental change for more than a decade [20,43,44]. Experience suggests that local institutions flourish when an NGO or government team provides backstopping support to help resolve smaller conflicts and remain 'paper committees' when there is no one they can call $[20,22,25]$.

Coastal villages and the fishery sector generally is an important sector from a poverty alleviation, adaptive capacity and economic development perspective. Fisheries contribute around seven percent of Gross Domestic Product (GDP), and this sector employs 10.5 percent of Cambodians on a full-time basis along with an additional 34 percent of people being employed on a part time basis [8]. Cambodians rely on a significant amount of fish products as their primary source of protein (consuming, on average, 52 kilograms per year as compared with other animal proteins, which are consumed at levels below 10 kilograms per year) [8]. Cambodia is seen to have lower levels of adaptive capacity to climate change than other countries in the region [45], in large part a product of high aid dependency (nine percent of GDP), limited state capacity, high levels of poverty and a 
dependence on natural resources for many rural livelihoods [46]. A collapse in fish stocks, from over-fishing or climate variation, will be felt far beyond the local level.

\section{Approach, Data Collection and Analysis}

To understand environmental change and the role of local institutions in resource management in coastal areas, a multi-method case study approach was utilized in Peam Krasaop Wildlife Sanctuary. This area $(23,750$ hectares) was designated as a coastal protected area in 1993. There are over 40 mangrove species, including Rhizophora spp. along the mangrove estuaries, and a mix of species in the extensive rear or depression areas, e.g., Bruguiera spp., Xylocarpus spp., Avicennia spp. [47]. Many aquatic species move through Peam Krasaop Wildlife Sanctuary at some point in their life cycle, including grouper fish (Epinephelus tauvina and Epinephelus awoara), swimming and mangrove mud crabs (Callinectes sp., Scylla sp.) and several species of shrimp (Penaeus sp., Metapenaeus sp.). Around 8750 people (according to 2009 statistics) live in the wildlife sanctuary.

We focus on five mangrove-estuary fishing villages that have developed resource management institutions at some point over the past fifteen years. All five villages have local institutions (referred to as resource management committees) that are officially recognized by the Ministry of Environment. Within and between these five villages, there is a continuum of dependence upon fishing resources, with fishing being the most important livelihood in four out of five villages. Fishers classify themselves as small scale, using crab traps and gill nets in the mangrove-estuary areas or using gill nets and small trawls in the near shore areas along the coast. Peeling crabs for their meat or smallholder agriculture (three villages have access to some form of agricultural land) is another important livelihood activity.

We picked this area as a research site, because of a history of local institutions working on resource management (particularly fishery issues) in this area [23,48]. Case-specific research questions and data collection addressed core research questions of livelihood challenges, environmental change, the types of projects funded by donors in the area and the role of local institutions in managing resource challenges. Data collection included semi-structured interviews, focus group discussions and participant observation (see Table 1). The research builds on findings and data from a series of investigations in the case study area, secondary literature and a review of environmental change literature for southwestern Cambodia [48-50].

Villagers who have been fishing and earning a livelihood from natural resources in Peam Krasaop Wildlife Sanctuary hold a series of observations concerning environmental change. Local committee members actively working to address local challenges hold strong institutional memory in terms of the types of projects that have been tried in the area, what works and what does not and the livelihood challenges they continue to face. This combination of interviews with fishers and representatives of local institutions has shed the following insights onto perceptions of environmental change, the role of local institutions and general resource management work found in Peam Krasaop Wildlife Sanctuary, in coastal Cambodia. We draw on these insights to then further reflect on the kinds of adaptation projects local institutions can work on and where greater higher-level support is necessary to deal with environmental change. 
Table 1. Research methods.

\begin{tabular}{|c|c|c|}
\hline Level & Description of methods & Timeframe \\
\hline \multirow{3}{*}{$\begin{array}{l}\text { Local institutions in } \\
\text { Peam Krasaop } \\
\text { Wildlife Sanctuary, } \\
\text { Cambodia }\end{array}$} & Key informant interviews $(\mathrm{n}=15)$ & $\begin{array}{l}\text { 2011-2012 (May, September, } \\
\text { February) }\end{array}$ \\
\hline & Focus group discussions $(\mathrm{n}=10 ; 8$ people/focus group) & 2011 (May, September) \\
\hline & Participant observation & 1998-2012, annual visits to area \\
\hline Government actors & Key informant interviews $(\mathrm{n}=5)$ & 2012 (February) \\
\hline Secondary sources & Literature review & 2011-2013 \\
\hline
\end{tabular}

\section{Results}

\subsection{Perceptions of Environmental Change}

Villagers observed three broad categories of environmental change, including species loss or decline, irregularity of tides and shifting weather patterns. The intensity of the observation was linked with the geography of a particular village. For example, species loss was commented on more often in mangrove-estuary fishing villages compared with coastal villages that also had access to farmland. In contrast, mangrove-estuary villages spoke less about flooding than in more exposed coastal areas that were less buffered by mangrove trees. Table 2 compiles this information, highlighting observed changes within all five villages, explaining why people believe this change is happening, the perceived impacts of an observed change, and any local responses.

Table 2. Local perceptions of environmental change.

\begin{tabular}{|c|c|c|c|}
\hline Observed change & Explanation & Impacts & Response \\
\hline Irregularity of tides & $\begin{array}{l}\text { Tides are harder to predict, } \\
\text { and the duration of tides has } \\
\text { shifted (from two to four or } \\
\text { five hours). }\end{array}$ & $\begin{array}{l}\text { Crab fishers can no longer lay } \\
\text { their traps during low tide, } \\
\text { when crabs are attracted to } \\
\text { bait, and be ensured the traps } \\
\text { will soon be submerged. }\end{array}$ & $\begin{array}{l}\text { Some fishers monitor traps } \\
\text { more consistently. } \\
\text { Measuring peak floods } \\
\text { since } 2004 \text {, it is believed } \\
\text { that there has been a rise of } \\
0.1 \text { meter since then. }\end{array}$ \\
\hline $\begin{array}{l}\text { Shift in weather } \\
\text { patterns }\end{array}$ & $\begin{array}{l}\text { A perceived rise in } \\
\text { temperature and change in } \\
\text { seasons; heavier rains and } \\
\text { increasing storms and floods. }\end{array}$ & $\begin{array}{l}\text { Storms affect access to fishing } \\
\text { grounds; intense heat affects } \\
\text { sea grass; beaches are eroding } \\
\text { and mangrove stands are } \\
\text { being damaged. }\end{array}$ & $\begin{array}{l}\text { Keep notes of houses } \\
\text { destroyed by floods; } \\
\text { considering a change in } \\
\text { house design. }\end{array}$ \\
\hline Species decline & $\begin{array}{l}\text { Some aquatic species have } \\
\text { become rare in the past few } \\
\text { years, as pressure on aquatic } \\
\text { resources have intensified. }\end{array}$ & $\begin{array}{l}\text { People need to fish; "harder" } \\
\text { to survive. }\end{array}$ & $\begin{array}{l}\text { Tried many activities: } \\
\text { patrolling, protesting } \\
\text { against sand mining and } \\
\text { trawls; but general declines } \\
\text { continue. }\end{array}$ \\
\hline
\end{tabular}

Fishers argued that tides are irregular and harder to predict than in the past. Crab fishers can no longer set their crab traps at low tide and assume that they will be submerged (sometimes tides creep up so quickly that crab traps are covered in water before the crabs can enter, and at other times, the traps remain un-submerged). As a consequence, fishers need to monitor their traps more carefully, 
either fishing closer to home with the consequence of having less overall catch or spending greater time away from home and sleeping on their fishing boats (in this scenario, people report catching more crabs, since fewer people are fishing for crabs further away from the villages). This forced behavior change is not something fishers are happy about. As one crab fisher comments, "I am old now and do crab fishing because I want to fish near the village. I want to sleep at home, not on the fishing boat. If the changes continue, the lives of fishers will be harder and harder, and fishing activities will disappear one day".

Floods and storms have always been present in this area, particularly in the rainy season. For example, in 1998, one fisher explained that he was "... afraid to go fishing very far from home in the rainy season. The waves are big, the wind is strong and the storms are terrible" [50]. However, fishers perceive that the intensity and frequency of storms is shifting. People talk about storms damaging their homes or, in a few instances, mangrove trees. With such intense storms come floods. Measurements by one village chief suggest that the level of flooding has increased by one decimeter (39.37 inches) since 2004. In another village, it was noted that more homes were destroyed in 2011 than were destroyed in 2010 by flooding (30 homes as of September, 2011, as compared with 10 homes throughout 2010). There has been no specific meteorological data collected for coastal Cambodia, and while general scientific data suggests that precipitation and heavy rains have been consistent throughout Cambodia since 1960 [51], it may be that the timing or intensity of flooding is changing, that general trends for inland Cambodia do not hold true in Cambodia's coastal area or that climate change is the lens through which people explain livelihood challenges. Regardless, flooding and storm frequency in coastal areas requires careful monitoring.

Fishers also comment on an overall rise in temperature, something that farmers have observed in other parts of Cambodia [46]. This observation is confirmed by long-term scientific monitoring: the mean annual temperature for Cambodia has increased by 0.8 degrees Celsius since 1960 [51]. Intensifying hot seasons can have multiple impacts upon fisheries. As one interviewee noted, "the weather patterns are changing. I no longer can follow the water patterns to find krill. It is sometimes too hot, and the rainy season is shifting so that I can no longer use my traditional knowledge". Shifting temperatures impact fishing options, particularly for those fishing in shallow-water areas, whereby the hot sun easily penetrates the waters' surface, or for those practicing some form of small-scale fish grow out, whereby prolonged heat waves can kill an entire fish crop.

Changes in species composition and quantity are complicated to understand, since fisheries tend to fluctuate, there is no baseline data for coastal Cambodia and fishery management has been poor [52]. Fishers have talked about species loss for over a decade. For example, in interviews from fifteen years earlier (1998) that took place in several of the study villages, fishers noted several species that had become rare (i.e., Parastromateus niger or Istiophorus platypterus) and also commented on changes in consumer tastes (i.e., people now eat frog fish, Antennarius spp.) [48]. In contrast, fishers in 2012 spoke extensively about species size, since it is now hard to find large grouper fish (Epinephelus tauvina, Epinephelus awoara) on a consistent basis and crabs (Callinectes sp., Scylla sp.) are smaller than in the past. Rather than targeting large groupers in deeper waters, fishers now target red fish (Lutjanus spp.) and blue crabs ( $P$. pelagicus) in deeper waters. In the mangrove-estuary areas, Marschke and Berkes [53] already warned of a collapse in crab species, due to the number of pre-reproductive species being caught in the early 2000s; a complete collapse does not appear to have 
happened, and over-fishing has been seen as an issue for over a decade. Overall, fishery decline is attributed to the use of certain types of fishing gear (large trawls, circle nets) and the impacts of large-scale sand extraction taking place in this area since 2008. At the same time, our interviewees admitted that they respond to fishery declines by increasing their own fishing effort and decreasing the mesh size on their traps or gill nets. Another coping strategy appears to be migration, both for individual household members and for entire households [20].

Another crab fisher nicely sums up the challenges fishers face in this area:

Since starting to fish, in 1992, I have had to continuously increase the number of nets that I use while decreasing my mesh size. There are some seasons that are better than other seasons, but in general, we all have to work harder than we did in the past. Now that it is hotter than before does not help. The future of a fisher is not good. Some fishers may be forced to do something like moving out of the village to an area where they can pursue agriculture and animal raising.

Environmental change is experienced in coastal villages in complex ways, and it is unclear how much can be attributed to shifts in climate patterns, over-fishing and general fluctuations. At this point, over-fishing may be the most critical issue, although climate projections certainly suggest that coastal areas will face real impacts from climate variation (sea level rise, loss of certain species). Fishers acknowledge that fishing has never been an easy livelihood and that general stock declines continue to have a direct impact on their livelihood (fishers have to fish harder to make a living). Add in climate variation, where a lot of uncertainty lies, since it is unclear how this will play out, and smaller scale fishing livelihoods become even more complicated.

\subsection{Local Institutions Responding to Environmental Change}

In response to such challenges, local institutions in Peam Krasaop Wildlife Sanctuary, often with donor backing, have been working to address environmental change issues since the 1990s (see Table 3). This led to the replanting of over 850 ha of mangroves since 2000, with satellite imagery showing that an additional 7000 ha of mangroves cut in the 1990s had experienced some form of natural re-growth by 2007. Mangrove replanting and forest protection has resulted in a perceived increase of one crab species in the area (the mangrove mud crab), ensured a buffer for wind, storms and, to a lesser extent, floods in some villages and created a general appreciation for mangrove conservation [20]. As one villager noted, "It is well known to others that we protect our mangroves. This is a common property area that is protected. Sure, some people try to come to cut the mangroves, but this happens in very few places". Other activities, such as the creation of artificial reefs [54], have provided habitat for aquatic species, while limiting trawls in shallow-water bay areas. From a communication perspective, the creation of a fishery federation enabled village committees to work as a larger unit in terms of protesting over-fishing and the impacts of sand mining activities at a provincial and a national level. Finally, ecotourism work is seen as a successful blend of entrepreneurship and of mangrove protection, particularly in one village, where they have built over 600 meters of pathways through the mangroves and a 17-meter observation tower. In sum, this is a group of villages with local institutions that have a significant, longer-term experience in thinking about environmental issues, linking this to their 
livelihood challenges and being realistic about what might be sustainable in terms of development projects. See Table 3.

Table 3. Local institutions, key activities and leadership characteristics.

\begin{tabular}{|c|c|c|c|}
\hline Village & Donor funds ${ }^{a}$ & Key activities, 2000-2012 & $\begin{array}{l}\text { Brief explanation of leadership } \\
\text { within committee }\end{array}$ \\
\hline A & Yes & $\begin{array}{l}\text { Mangrove re-planting; waste management; } \\
\text { patrolling; fish sanctuary; skill development (hair } \\
\text { dressing, engine and radio repair); lead committee } \\
\text { in fishery federation, women's savings group. }\end{array}$ & $\begin{array}{l}\text { Strong leadership }{ }^{\text {b }} \text {; long-term } \\
\text { support from outside projects } \\
\text { (since 1997); high-level } \\
\text { provincial connections. }\end{array}$ \\
\hline B & Yes & $\begin{array}{l}\text { Committee elected in 2011; rules and regulations } \\
\text { are new. }\end{array}$ & $\begin{array}{l}\text { Committee chief appears committed, } \\
\text { but not active yet. }\end{array}$ \\
\hline $\mathrm{C}$ & Yes & $\begin{array}{l}\text { Environmental education; integrated farming } \\
\text { systems; skill development (hair dressing, engine } \\
\text { and radio repair); some mangrove replanting; } \\
\text { artificial reefs. }\end{array}$ & $\begin{array}{l}\text { Weak leadership (committee head } \\
\text { not respected by villagers); fishing } \\
\text { challenges are extra complicated } \\
\text { due to geography. }\end{array}$ \\
\hline $\mathrm{D}$ & Yes & $\begin{array}{l}\text { Patrolling; integrated farming system; skill } \\
\text { development (hair dressing, engine and radio } \\
\text { repair); eco-tourism, including fishing platforms } \\
\text { for tourists. }\end{array}$ & $\begin{array}{l}\text { Active, well-organized leader; } \\
\text { support of provincial departments, } \\
\text { linked to proximity (a quick boat ride } \\
\text { from town). }\end{array}$ \\
\hline $\mathrm{E}$ & Yes & $\begin{array}{l}\text { Eco-tourism (since the mid-2000s); fish and sea } \\
\text { grass sanctuary; integrated farming system; skill } \\
\text { development (hair dressing, engine and radio } \\
\text { repair); installment of drinking water system; some } \\
\text { patrolling; some mangrove replanting. }\end{array}$ & $\begin{array}{l}\text { Active, respected politically-connected } \\
\text { leader; long-term support from } \\
\text { outside projects (since 1997); } \\
\text { the commune chief is also the } \\
\text { committee chief. }\end{array}$ \\
\hline
\end{tabular}

${ }^{a}$ Funds for environment or resource management-type work come from the following organizations: SCW, Save Cambodia's Wildlife; Danish International Development Agency (DANIDA); IDRC, International Development Research Center (Canadian aid); UNDP, United Nations Development Program (UNDP UN funds); MAP, Mangrove Action Project (Thai-based NGO); IUCN, International Union for Conservation of Nature (global conservation organization); ${ }^{\mathrm{b}}$ In 2012 the leader resigned from the committee. The committee has a new leader, but is struggling to carry out its work.

As Table 3 indicates, local institutions have been involved in a range of activities related to resource management, environmental change and livelihoods, some which are more successful than others. Success is linked to local leadership [55], donor support [20], the choice of activity and broader political-economy issues (how external factors influence this area). For example, when local leaders are active and politically connected, they have a greater chance of finding a series of activities that will work and can handle setbacks if a particular activity fails. At the same time, protection projects (fish and sea grass sanctuaries, mangrove replanting) and ecotourism projects (creating picnic platforms in the mangroves, taking tourists to fish in and around a green mussel culture) are regarded as the most successful kinds of environmental projects. Protection activities help buffer against species decline and loss; ecotourism is a money-making enterprise, which enables villagers to benefit from their resource-protection work, and can generate funds for local institutions to sustain their activities once project money has dried up. 
This said, local institutions need far greater support in handling environmental change issues and for supporting their livelihoods in general. Combatting sea level rise will likely take some form of infrastructure development or support to build homes in different ways; responding to changing weather patterns will require fishers, local institutions and scientists to take the time to meet together to consider realistic options; finally, species decline and loss requires sustained patrols and adherence to national and regional policies. While several local institutions have attempted to organize systematic fishery patrols to monitor for illegal activities, they have had little support from local police or provincial institutions, making it difficult to sustain. Policy exists for local institutions to take an active role in patrolling, yet policy uptake remains weak at provincial and district levels [56]. Sand mining, which is believed to greatly affect fish stocks, has also proven to be a contentious issue. Global Witness [57] highlights the prevalence of sand dredging. By 2010, there were an estimated 27 dredging sites in this area. Fishers suspect that sand mining is linked to the rapid disappearance of the swimming crab species. The fishery federation protested at the provincial level and sent thumb-printed petitions to several national institutions, all to no avail. The owner of the sand mining operation was allegedly connected to those in the highest levels of government; no one could touch this issue, even though local fishing livelihoods were being significantly impacted [20,57,58]. In 2012, sand mining operations had begun to move away from this area, although other fishing villages are now likely facing similar challenges.

Linking environmental change work with income generation projects generally remains challenging for local institutions (with the exception of ecotourism, which requires closer examination) and the NGOs working on such projects. While local committees and NGO teams have worked together to introduce a series of training activities, many are not sustained past the life of a project. For example, one women's savings group fell apart when the group leader ran away with all the funds. Villagers are now hesitant to create another savings group. Some youth had the chance to be trained in engine repair, with the idea that they could then service boats in the villages. To our knowledge, these youth now use these skills to repair their own boats, but none opened a village repair shop (villagers go to the provincial town for this service). Good ideas do not necessarily translate into workable solutions, particularly in more isolated coastal fishing villages. To be fair, it is not easy to find solutions to the environmental and socio-economic challenges facing coastal villagers.

Local institutions acknowledge that bigger political economy issues are not something that they can easily touch and have become disappointed when funders, government officials and organizations they are working with cannot help to address such issues. As one committee member noted, "often, outsiders come in and tell us what to do. We often listen, since they sometimes know more than us, but it is hard when we ask for support on issues that we cannot solve, and they say that they cannot help us". In recent years, villagers have begun to voice that they often do far more work than government institutions or NGOs and that it is not always worth their while to be involved in such efforts. The head of another resource management institution noted, "When we list the things we most need help with, they [donor representatives] say they understand, but that they also have to answer to higher people and that only certain types of projects will get funded. Since we live in a protected area, it is always environmental projects, but we have found these do not always help us to earn money, and we do need to survive". This quote speaks to a very real challenge: people need to make a livelihood from their environment, and a mix of development and resource management projects are required to sustain people. 
The history of aid projects in this area is important to recognize, particularly with the emerging shift towards climate change adaptation projects and with a potentially new set of donors coming into this area to fund projects within an adaptation lens. Not all projects are successful or realistic at a local level. Village institutions have significant local memory and can help shape realistic interventions and can point out sustainability challenges that require uptake far beyond the village level.

\section{Discussion and Conclusions}

Environmental change is perceived to be a real phenomenon by fishers in Peam Krasaop Wildlife Sanctuary and consists of a combination of stock declines, shifting weather patterns and changes in tide patterns, which affects fishing techniques and catch levels, among other things. Fishers do not perceive climate variation and change to be the main reason for stock declines (they attribute this to general over-fishing, particularly by larger trawls, but also themselves); although, they do feel that climate variation and change is likely also having an impact upon their fishing practices. In a sense, climate change has emerged as a convenient lens by which to discuss broader environmental challenges facing fishers in Peam Krasoap Wildlife Sanctuary, particularly since over-fishing vis-à-vis patrolling is something villagers have tried to address over the years with little outside support. While it is important to understand the relationship between people's perceptions and measurable phenomena to ensure that appropriate responses are generated for environmental change, explaining a situation through a climate change lens may also be a new way that local people and NGOs can generate resources for people within an area. Thus, in-coming climate change adaptation projects may be able to help with certain aspects of village life.

Worth noting, local perceptions relating to climate change are not so different from what scientists generally suggest, keeping in mind the limited climate data that exists specifically for Cambodia. Coastal villages do face considerable risks, which will likely increase according to climate change models [4,59], and extreme weather events are on the rise [60]. Moreover, Perry [1] observes that climate-related threats for mangrove estuaries include sea level rise and rising temperature, resulting in habitat loss, altered productivity, changing growth rates and increased desiccation at low tide. This is not an easy moment to be a small-scale fisher or to live in a tropical coastal area, whereby over-fishing is felt and the impacts of climate change and variation are also starting to be felt. Fishing these days demands increased effort, and people question how long this might be sustained. At the same time, not everyone has the option to switch into non-fishing activities. An important aspect of adapting to environmental change is thinking through short-term versus longer-term needs of fishers and of the environment.

While local institutions may have ideas that can somewhat dampen the impacts of climate change and over-fishing, our longitudinal approach highlights the reality of the kinds of commons dilemmas that local institutions (resource-focused committees) can and cannot approach. Many projects are not sustained over time. While local institutions are well placed to deal with certain types of environmental change, particularly concrete actions, such as on-going monitoring, tree replanting or undertaking livelihood trials to consider a host of options for fishing or fish raising in warmer waters, higher level institutions also need to be involved in the day-to-day management of environmental change challenges. Far greater investment is needed to enforce current fishery policies (to handle over-fishing), 
and to carefully think through the types of adaptation measures that could make a difference (i.e., ensuring that NAPAs are written in a succinct manner, with concrete actions directed at fishing villages). Ribot [11] (p. 1162) notes how adaptation is a term that "lends itself to shedding the burden of response onto vulnerable parties; naturalizing what are socially generated conditions". For such cases, the burden of adaptation cannot only be upon poor, under-resourced local institutions (although, there is no doubt that they may have some innovative coping strategies), rather a multi-level, coordinated governance approach would be more appropriate. There is a need to consider commons management from a multiscalar perspective if activities are to be effective and, in many cases, sustained.

Fishery declines, climate variability and change are challenges that will require significant attention beyond the local level; there is a need to move decision-making beyond the scale of a single fishery and to consider the climatic and non-climatic benefits of any adaption intervention [61]. Table 4 outlines key actions that could enhance environmental change projects in Cambodia. On the one hand, there is a need for the long-term monitoring of environmental change in the coastal area, combined with work on regional modeling to better anticipate changes that might occur. If a series of coastal sites were selected for consistent monitoring, this would help with decision-making in the face of growing uncertainties. Moreover, there is a need to develop models that consider climatic shifts, stock declines and economic development [1], particularly for global South nations. Local committees could be involved in this. There is enough science to have a sense of what is happening, both with regards to over-fishing and climatic variation and change; this information coupled with local observations of change could produce an authoritative, locally-relevant picture. Finally, given the challenges facing coastal villages and the fishery sector more generally, engaging fishers, scientists and planners together in a series of planning activities would likely produce powerful response scenarios for the Cambodian context, which could then assist in adaptation plans and in planning for and in implementing specific interventions.

Table 4. Action areas for addressing aspects of environmental change.

\begin{tabular}{ll}
\hline Issue & Action \\
\hline $\begin{array}{l}\text { Lack of environmental } \\
\text { change data }\end{array}$ & $\begin{array}{l}\text { Monitor coastal perceptions of environmental change on a consistent basis. } \\
\text { Combine this information with on-going scientific analysis to form the basis of } \\
\text { any adaptation strategy. }\end{array}$ \\
\hline $\begin{array}{l}\text { Strengthen fishery } \\
\text { issues within national } \\
\text { plans }\end{array}$ & $\begin{array}{l}\text { National planning documents need to move beyond vague discussions of fishery } \\
\text { issues. Key areas to consider include: anticipating what species may move into } \\
\text { cooler waters and how this will impact Cambodian fishers; the role of } \\
\text { aquaculture and what species make sense to fish or farm. }\end{array}$ \\
\hline Over-fishing & $\begin{array}{l}\text { Over-fishing is a known issue throughout the region. Enforcing existing policies } \\
\text { is an important step, particularly in the short to medium term. More money needs } \\
\text { to be dedicated to policing by national or provincial officials. }\end{array}$ \\
\hline Livelihood challenges & $\begin{array}{l}\text { Fishing livelihoods remain precarious. Environmental change planning has to be } \\
\text { linked to potential future livelihood strategies (fishing and non-fishing). }\end{array}$ \\
\hline $\begin{array}{l}\text { Communication with } \\
\text { local institutions }\end{array}$ & $\begin{array}{l}\text { Communication between scientists, planners and local fishery institutions is } \\
\text { critical for developing response scenarios to climate change impacts and } \\
\text { environmental change more generally on marine social-ecological ecosystems. }\end{array}$ \\
\hline
\end{tabular}




\section{Acknowledgments}

This research was funded by the Social Sciences and Humanities Research Council of Canada. A special thanks to all those that took the time to meet with us.

\section{Author Contributions}

M. Marschke was the lead author on this paper, with O. Lykhim and N. Kim contributing significantly to fieldwork coordination, participant interviews, data analysis, and writing.

\section{Conflicts of Interest}

The authors declare no conflict of interest.

\section{References and Notes}

1. Perry, I.; Ommer, R.; Barange, M.; Jentoft, S.; Neiss, B.; Sumaila, R. Marine social-ecological responses to environmental change and the impacts of globalization. Fish Fish. 2011, 12, 427-450.

2. Pitcher, T.J.; Lam, M.E. Fishful thinking: Rhetoric, reality, and the sea before us. Ecol. Soc. 2010, 15, Article 12.

3. Badjeck, M.-C.; Allison, E.H.; Halls, A.S.; Dulvy, N.K. Impacts of climate variability and change on fishery-based livelihoods. Mar. Policy 2010, 34, 375-383.

4. Cheung, W.; Lam, V.; Sarmiento, J.; Kearney, K.; Watson, R.; Pauly, D. Projecting global marine biodiversity impacts under climate change scenarios. Fish Fish. 2009, 10, 235-251.

5. Adger, N. Commentary-Four reasons for concern about adaptation to climate change. Environ. Plann. A 2009, 41, 2800-2805.

6. Worm, B.; Branch, T. The Future of Fish. Trends Ecol. Evol. 2012, 27, 594-599.

7. Axelrod, M. Climate Change and Global Fisheries Management: Linking issues to protect ecosystems or save political interests? Global Environ. Polit. 2011, 11, 64-85.

8. Allison, E.H.; Ratner, B.D.; Åsgård, B.; Willmann, R.; Pomeroy, R.; Kurien, J. Rights-based fisheries governance: From fishing rights to human rights. Fish Fish. 2011, 13, 14-29.

9. Béné, C.; Hersoug, B.; Allisson, E.H. Not by rent alone: Analyzing the pro-poor functions of small-scale fisheries in developing countries. Dev. Policy Rev. 2010, 28, 325-358.

10. Berrang-Ford, L.; Ford, J.D.; Peterson, J. Are We Adapting to Climate Change? Global Environ. Change 2011, 21, 25-33.

11. Ribot, J. Vulnerability before Adaptation: Towards transformative climate action. Global Environ. Change 2011, 21, 1160-1162.

12. Clements, T.; John, A.; Nielsen, K.; An, D.; Tan, S.; Milner-Gulland, E. Payments for Biodiversity Conservation in the Context of Weak Institutions: Comparison of Three Programmes from Cambodia. Ecol. Econ. 2010, 69, 1283-1291.

13. Milne, S.; Adams, B. Market Masquerades: Uncovering the Politics of Community-level Payments for Environmental Services in Cambodia. Dev. Change 2012, 43, 133-158.

14. Scoones, I. Livelihoods Perspectives and Rural Development. J. Peasant Stud. 2009, 36, 171-196.

15. Sen, A. Poverty and Famines: An Essay on Entitlement and Deprivation; Oxford University Press: New York, NY, USA, 1981. 
16. Leach, M.; Mearns, R.; Scoones, I. Environmental Entitlements: A framework for understanding the institutional dynamics of environmental change. Available online: http://dlc.dlib.indiana.edu/ dlc/bitstream/handle/10535/3716/leach-et-al-environment_entitlements_a_framework_for_ understanding_the_institutional_dynamics_of_environmental_change.pdf?sequence $=1$ (accessed on 22 January 2012).

17. Blaikie, P.; Brookfield, H. Land Degradation and Society; Methuen \& Co. Ltd.: London, UK, 1987.

18. Wisner, B.; Blaikie, P.; Cannon, T.; Davis, I. At Risk; Routledge: London, UK, 2004.

19. Smit, B.; Wandel, J. Adaptation, adaptive capacity and vulnerability. Global Environ. Change 2006, 16, 282-292.

20. Marschke, M. Life, Fish and Mangroves: Resource Governance in Coastal Cambodia; University of Ottawa Press: Ottawa, ON, Canada, 2012.

21. Bowen, K.; Miller, F.; Dany, V.; McMichael, A.; Friel, S. Enabling environments? Insights into the policy context for climate change and health adaptation decision-making in Cambodia. Clim. Dev. 2013, 5, 277-287.

22. Kurien, J.; Nam, S.; Onn, M.; Inland Fisheries Research and Development Institute. Cambodia's Aquarian Reforms: The emerging challenges for policy and research. Available online: http://ideas.repec.org/b/wfi/wfbook/37163.html (accessed on 3 May 2013).

23. Participatory Management Coastal Resources. Learning for Change: Ten Years of Experience on Community Based Coastal Resource Management and Livelihood Improvement in Koh Kong, Cambodia; CBNRM Learning Institute: Phnom Penh, Cambodia, 2008.

24. CBNRM Learning Institute. Emerging Trends, Challenges and Innovations for CBNRM in Cambodia. Available online: http://www.kh.boell.org/downloads/CBNRM_full_document.pdf (accessed on 15 August 2013).

25. Kurien, J. On Developing Guidelines for Securing Sustainable Small-Scale Fisheries: Sharing Processes, Resources, and Lessons Learnt from Cambodia; Project Report (Draft); Food and Agricultural Organization: Rome, Italy, 2014.

26. Although commune councils may be involved in environmental work within our field site, the main local institutions that we are referring to are locally-elected community fisheries or community-based protected area management committees. Committee members, of which there are seven, are selected from village-level candidates and elected for three-year terms. Committee members may be linked to commune councils or may have a particular political agenda, but most often are the village "movers and shakers" interested in making change happen. For further details of committee composition and work, see [20].

27. Berkes, F. Devolution of Environment and Resources Governance: Trends and Future. Environ. Conserv. 2010, 37, 489-500.

28. Ostrom, E. A General Framework for Analyzing Sustainability of Social-Ecological Systems. Science 2009, 325, 419-422.

29. McCay, B., Acheson, J., Eds. The Question of the Commons: The Culture and Ecology of Communal Resources; University of Arizona Press: Tuscon, AZ, USA, 1987.

30. Schlager, E.; Ostrom, E. Property-rights regimes and natural resources: A conceptual analysis. Nature 1992, 413, 591-596. 
31. Cox, M. Balancing Accuracy and Meaning in Common-Pool Resource Theory. Ecol. Soc. 2008, 13, Article 44.

32. Andersson, K.; Ostrom, E. Analyzing Decentralized Resource Regimes from a Polycentric Perspective. Policy Sci. 2008, 41, 71-93.

33. Khumsri, M.; Ruddle, K.; Shivakoti, G. Rights and Conflicts in the Management of Fisheries in the Lower Songkhram River Basin, Northeast Thailand. Enviorn. Manag. 2009, 43, 557-570.

34. Berge, E.; van Laerhoven, F. Governing the Commons for two decades: A complex story. Int. J. Commons 2011, 5, 160-187.

35. Agrawal, A. Forests, Governance, and Sustainability: Common property theory and its contributions. Int. J. Commons 2007, 1, 111-136.

36. Barsimantov, J.; Racelis, A.; Biedenweg, K.; DiGiano, M. When Collective Action and Tenure Allocations Collide: Outcomes from Community Forests in Quintana Roo, Mexico and Peten, Guatemala. Land Use Policy 2011, 28, 343-352.

37. Rigg, J., Vandergeest, P., Eds. Revisiting Rural Places: Pathways to Poverty and Prosperity in Southeast Asia; National University of Singapore Press: Singapore, 2012.

38. Ministry of Agriculture, Forestry and Fisheries. The Strategic Planning Framework 2010-2019 for Fisheries-Fishing for the Future. Available online: http:/www.google.com.hk/url?sa=t\& $\mathrm{rct}=\mathrm{j} \& \mathrm{q}=\&$ esrc $=\mathrm{s} \&$ source $=\mathrm{web} \& \mathrm{~cd}=1 \& \mathrm{ved}=0 \mathrm{CCkQFjAA} \& u r \mathrm{~h}=\mathrm{http} \% 3 \mathrm{~A} \% 2 \mathrm{~F} \% 2 \mathrm{Fwww}$.imm.uk. com\%2FDS\%2FOpen.aspx\%3Fid\%3D7ca41470-d384-4a79-9cd8-c4c1c92cc195\&e=akJOU_ uML9W_sQT76oHoCg\&usg=AFQjCNEpZwO8q81XENOsbWurM5A8NQ-0Kg (accessed on 09 September 2013).

39. Ministry of Environment of Cambodia. National Adaptation Program of Action To Climate Change. Available online: http://unfccc.int/resource/docs/napa/khm01.pdf (accessed on 11 April 2011).

40. Ministry of Environment of Cambodia. National Adaptation Program of Action To Climate Change Updated Plan; Ministry of Environment of Cambodia: Phnom Penh, Cambodia, 2012.

41. D’Agostino, A.; Sovacool, B. Sewing climate-resilient seeds: Implementing climate change adaptation best practices in rural Cambodia. Mitig. Adapt. Strateg. Glob. Change 2011, 16, 699-720.

42. Mahanty, S.; Dressler, W.; Milne, S.; Filer, C. Unravelling property relations around forest carbon. Singap. J. Trop. Geogr. 2013, 34, 188-205.

43. Evans, P. Fishing Disarmed. Available online: http://dlc.dlib.indiana.edu/dlc/bitstream/handle/ 10535/2836/art02.pdf?sequence=1 (accessed on 05 October 2013).

44. Evans, P.; Marschke, M.; Paudyal, K. Community Forest Management Trends in Southeast Asia. Available online: http://www.asiaforestnetwork.org/rcs.htm (accessed on 24 January 2012).

45. Yusuf, A.A.; Francisco, H. Climate Change Vulnerability Mapping for Southeast Asia. Available online: http://web.idrc.ca/uploads/user-S/12324196651Mapping_Report.pdf (accessed on 11 November 2013).

46. United Nations Development Programme. Building Resilience: The Future for Rural Livelihoods in the Face of Climate Change. Available online: http://hdr.undp.org/en/content/building-resilience (accessed on 14 Novermber 2013).

47. Mastaller, M. Environmental Assessment of the Coastal Zone of Cambodia: Assessment of Sustainable Livelihood Alternatives to Mangrove Exploitation; Danish International Development Agency: Phnom Penh, Cambodia, 1999. 
48. Marschke, M. Mangrove Meanderings: Learning about life in Peam Krasaop Wildlife Sanctuary. Available online: https://idl-bnc.idrc.ca/dspace/bitstream/10625/30977/1/120827.pdf (accessed on 15 August 2012).

49. Eam, D. Changing Property Regimes and Community-based Fishery Management in Cambodia. Master Thesis, Chiang Mai University, Chiang Mai, Thailand, 2008.

50. Marschke, M. Using Local Environmental Knowledge: A Case-study of Mangrove Resource Management Practices in Peam Krasaop Wildlife Sanctuary, Cambodia. Master Thesis, Dalhousie University, Halifax, NS, Canada, 1999.

51. United Nations Development Programme. Climate Change Country Profiles. Available online: http://country-profiles.geog.ox.ac.uk (accessed on 10 April 2012).

52. Arthur, R.; Friend, R. Inland capture fisheries in the Mekong and their place and potential within food-led regional development. Glob. Environ. Change 2011, 21, 219-229.

53. Marschke, M.; Berkes, F. Local Level Sustainability Planning for Livelihoods: A Cambodian Experience. Int. J. Sustain. Dev. World Ecol. 2005, 12, 21-33.

54. Construction of the artificial reefs began in 2005; in early 2006, 414 concrete artificial reefs and 1000 cement poles were placed throughout Chrouy Pros Bay [50]. The artificial reefs serve two purposes: (1) as fish habitat; and (2) to prohibit trawl boats from using this area. For more details, see [20].

55. Marschke, M.; Sinclair, J. Learning for Sustainability through Participatory Resource Management. J. Environ. Manag. 2009, 90, 206-216.

56. Ratner, B.D.; Halpern, G.; Kosal, M. Catalyzing Collective Action to Address Natural Resource Conflict: Lessons form Cambodia's Tonle Sap. Available online: http://www.capri.cgiar.org/pdf/ capriwp103.pdf (accessed on 15 August 2012).

57. Global Witness. Shifting Sand: How Singapore's Demand for Cambodian Sand Threatens Ecosystems and Undermines Good Governance. Available online: http://www.globalwitness.org/ library/shifting-sand-how-singapore $\%$ E2\%80\%99s-demand-cambodian-sand-threatensecosystems-and-undermines-good (accessed on 14 November 2013).

58. Global Witness. Country For Sale: How Cambodia's Elite Has Captured the Country's Extractive Industries. Available online: http://www.globalwitness.org/sites/default/files/library/final_english.pdf (accessed on 14 November 2013).

59. Cheung, W.; Lam, V.; Sarmiento, J.; Kearney, K.; Watson, R.; Zeller, D.; Pauly, D. Large-scale redistribution of maximum catch potential in the global ocean under climate change. Glob. Change Biol. 2010, 16, 24-35.

60. Intergovernmental Panel on Climate Change. Special Report on Managing the Risks of Extreme Events and Disasters to Advance Climate Change Adaptation. Available online: http://ipcc-wg2.gov/ SREX/report/ (accessed on 11 December 2013).

61. Dovers, S. Normalizing adaptation. Glob. Environ. Change 2009, 19, 4-6.

(C) 2014 by the authors; licensee MDPI, Basel, Switzerland. This article is an open access article distributed under the terms and conditions of the Creative Commons Attribution license (http://creativecommons.org/licenses/by/3.0/). 